8. As nurse-in-charge of an asylum country walking party, what classes of patients would you desire to take or reject? What dangers might you anticipate and how would you guard against them, with special reference to density or sparseness of population and its consequences in the matter of towns, shops, traffic, fields, woods, etc. ?

Preliminary Examination.

The next examination will be held on Monday, November 4th, 1912.

\title{
Final Examination.
}

The next examination will be held on Monday, November I Ith, 1912.

\section{NOTICES OF MEETINGS.}

Quarterly Meeting.-The next meeting will be held at II, Chandos Street, Cavendish Square, on Tuesday, November 26th, 1912.

South-Western Division.-The Autumn Meeting will be held, by the courtesy of Dr. Mornington, at Laverstock House, Salisbury, on Thursday, October 24th, 1912.

Northern and Midland Division.-The Autumn Meeting will be held, on the invitation of Dr. Johnston and by the courtesy of the Asylum Committee, at Bracebridge Asylum, Lincoln, on Thursday, October 24th, 1912.

Scottish Division.-The Autumn Meeting will be held on Friday, November I5th, 1912.

Irish Division.-The Autumn Meeting will be held on Thursday, November 7 th, I912.

\section{APPOINTMENTS.}

Lind, W. A. T., M.D.Melb., Pathologist and Neurologist, Department of Lunacy, Victoria.

Parsons, L. D., M.B., Ch.B.Edin., Medical Superintendent of the Government Asylum, Colombo, Ceylon.

Clarke, J. Kilian, M.B., B.Ch., R.U.I., Assistant Medical Officer to the Essex and Colchester Asylum. 